\title{
Surgical Repair of Post Myocardial Infarction Ventricular Septal Defects: Single Center Experience of Fifteen Years
}

\section{Miyokard Enfarktüsü Sonrası Ventriküler Septal Defektlerin Cerrahi Onarımı: On Beş Yıllık Tek Merkez Deneyimi}

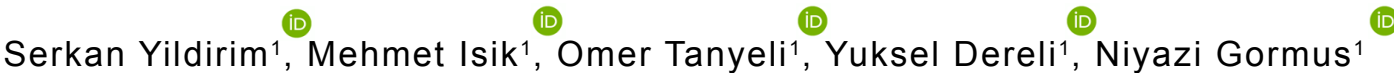

${ }^{1}$ Necmettin Erbakan University, Meram Faculty of Medicine, Department of Cardiovascular Surgery, Konya, Turkey

Address correspondence to: Serkan Yildirim, Necmettin Erbakan University, Meram Faculty of Medicine, Department of Cardiovascular Surgery, Konya, Turkey e-mail: serkaneo1@gmail.com

Geliş Tarihi/Received: 27 September 2021 Kabul Tarihi/Accepted: 6 November 2021

\begin{abstract}
Öz
Amaç: Miyokard infarktüsü sonrası ventriküler septal defektler (PMIVSD) nadirdir ancak son derece yüksek mortalite ve morbiditeye sahiptir. Mortalite oranları ve risk faktörleri birçok çalışmada farklılık göstermektedir.

Hastalar ve Yöntem: Ocak 2006 ile Nisan 2020 tarihleri arasında PMIVSD nedeniyle ameliyat edilen hastaları geriye dönük olarak 18 yaş ve üzeri kliniğimize dahil ettik.

Bulgular: Akut miyokard infarktüsü ile başvuran 9451 hastanın 28'i 2006-2020 yılları arasında PMIVSD nedeniyle merkezimizde ameliyat edildi. PMIVSD oranımız \% 0,296 idi. Hayatta kalanlar ile hayatta kalmayanları karşılaştırdığımızda istatistiksel olarak anlamlı olan tek şey hastanede kalış süresiydi. Sağ kalanlarda 2 gün iken, sağ kalmayan grupta 13 gündü $(p<0.001)$. Sağ kalan gruptaki bir hasta 107 gün hastanede kaldı.

Sonuç: PMIVSD hastaları için ameliyatın zamanlaması hala zordur. Sol ventrikül assist device (LVAD) veya perkütan cihazların implante edilmesi ve ameliyattan önce bir süre beklenmesi gibi diğer stratejiler. PMIVSD hastaları için daha iyi bir yaklaşım olacaktır.

Anahtar Kelimeler: Miyokard infarktüsü, ventriküler septal defektler, kardiyovasküler cerrahi

Abstract

Aim: Post-myocardial infarction ventricular septal defects (PMIVSD) are rare but have extremely high mortality and morbidity. Mortality rates and risk factors vary in many studies. We aimed to evaluate the mortality rates and risk factors of ventricular septal defects (PMIVSD) after myocardial infarction performed in our center.

Patients and Methods: We retrospectively enrolled the patients who underwent surgery for PMIVSD in our clinic from January 2006 to April 2020 with the age $\geq 18$.

Results: A total of 9451 patients admitted to our center with acute myocardial infarction between 2006 and 2020 were examined. Twenty-eight patients operated for PMIVSD were included in the study. Our PMIVSD rate was $0.296 \%$. When we compare those survivors and non-survivors the only thing which statistically significant was length of stay in hospital. In survivors it was 13 days when it 2 days in nonsurvivors group $(p<0.001)$. One patient in survivor group was stayed in hospital for 107 days.

Conclusion: Timing of the surgery for PMIVSD patients is still challenging. Further strategies like implanting LVAD or percutaneous devices and waiting for a while before the surgery will be the better approach for PMIVSD patients.
\end{abstract}

Key words: Myocardial infarction, ventricular septal defects, cardiovascular surgery
Cite this article as: Yildirim S, Isik M, Tanyeli O, Dereli Y, Gormus N. Surgery of Post Myocardial Infarction Ventricular Septal Defects: Single Center Experience of Fifteen Years. Selcuk Med J 2021;37(4): 301-306
Disclosure: None of the authors has a financial interest in any of the products, devices, or drugs mentioned in this article. The research was not sponsored by an outside organization. All authors have agreed to allow full access to the primary data and to allow the journal to review the data if requested. 


\section{INTRODUCTION}

Post-myocardial infarction ventricular septal defects (PMIVSD) are rare but have extremely high mortality and morbidity. Early reperfusion therapies reduced this complication at least $1-2 \%$ of all myocardial infarctions (1). Without immediate surgery mortality rate is very high $(60 \%)$ and less than $10 \%$ patients can alive for the first three months (2). ACC and AHA recommend immediate surgical repair because the rupture site can expand abruptly, resulting in sudden hemodynamic collapse in previously stable patients (3).

Female gender, advanced age and left anterior descending artery (LAD) infarction are risk factors for PMIVSD and they are associated with cardiogenic shock and death. As this complication is rare published series are small. The early mortality in series 19 to 66 $\%$ and the risk factors are still inconsonant. The aim of this study was to evaluate the clinical presentation and outcomes of patients which we have operated for PMIVSD in our clinic.

\section{PATIENTS AND METHODS}

This study is approved by the local ethics committee with the date 20.05.2020 and number of $2020 / 2515$. We retrospectively enrolled the patients who underwent surgery for PMIVSD in our clinic from January 2006 to April 2020 with the age $\geq 18$. The operations performed by six surgeons.

Patients admitted to our hospital between 20062020 are evaluated for the presence of PMIVSD. In our study, we included all the patients operated for PMIVSD, not the patients who received medical treatment. Acute myocardial infarction (MI) diagnosed by elevated cardiac enzymes, 30 minutes or longer chest pain and electrocardiographic changes. The ventricular septal defects (VSD) were diagnosed by transthoracic echocardiography in all cases. Preoperative medical problems (e.g. hypertension (HT), diabetes mellitus (DM), cerebrovascular events (CVE)), intraoperative balloon pump requirement and postoperative data were collected.

Cardiogenic shock was defined $<80 \mathrm{mmHg}$ systolic blood pressure or cardiac index below $1.8 \mathrm{~L} / \mathrm{min} / \mathrm{m} 2$, reduced urine output and signs of hypoperfusion despite maximal treatment. Postoperative 1 month and 3 months follow up done by outpatient clinic and 6 months follow up was done by phone contact who discharge from hospital. Operative mortality was the primary outcome and it was defined as the death within 30 days after surgery with any cause.

\section{Surgical Technique}

All patients were operated on through a median sternotomy with extracorporeal circulation and moderate hypothermia $\left(28-33^{\circ} \mathrm{C}\right)$. Cardiopulmonary bypass was established in all cases. All operations were performed from one to three days after the septal defect occurrence. Ventricular septal defect repair was performed via the left ventriculotomy side by LAD. Our surgical strategy had these steps: Approach to the interventricular septum through the area of the infarcted myocardium; closure of the VSD without tension with a Dacron or autologous pericardial patch with pledgets; infarctectomy until viable tissue reached and closure of the ventriculotomy without tension, usually with Teflon strips.

\section{Statistical Analysis}

Descriptive statistics of considered variables were given. Mean, standard deviations, median, q1 and q3

Table 1. Baseline characteristics of patients

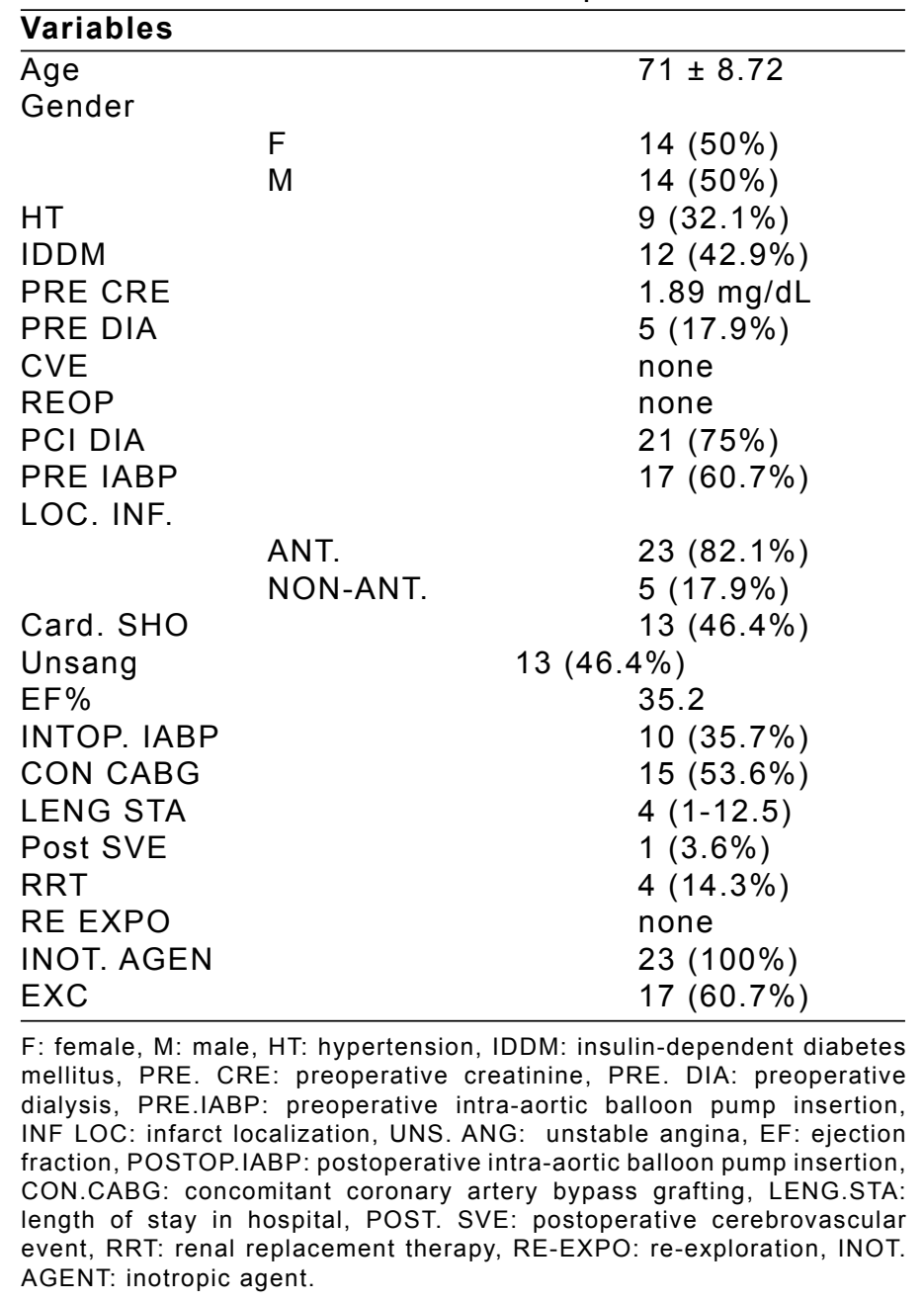


statistics were calculated for continuous variables. Categorical variables are displayed as frequency and percentages. Comparison of continuous variables among groups are done using Mann Whitney $U$ test and that of categorical variables are done using Chi square test. All statistical analysis was performed by Jamovi version 1.2.2.

\section{RESULTS}

28 patients were operated for PMIVSD at our clinic between 2006 - 2020. Our PMIVSD rate was $0.296 \%$. Seven of the 28 patients were brought to our center at the time of diagnosis; two of them three days, three of them two days and two of them one day after diagnosis from the other hospitals. The average age was $71 \pm 8.72$. The fourteen of the patients were women (50\%). Twelve patients (42.9 $\%)$ had insulin-dependent diabetes mellitus (IDDM) and nine $(32.1 \%)$ had hypertension. Five patients $(17.9 \%)$ needed preoperatively hemodialysis (HD)
(Table 1). Surgical treatment was performed all of the PMIVSD patients. Concomitant coronary artery bypass grafting (CABG) was performed in 15 patients (53.6 \%). 21 patients $(75 \%)$ underwent percutaneous coronary intervention (PCl) before operation. Intraaortic balloon pump (IABP) was needed in 17 patients $(60.7 \%)$ preoperatively. 23 of patients $(82.1 \%)$ had anterior MI. Cardiogenic shock was seen in 13 patients $(46.4 \%)$. The overall ejection fraction (EF) was 35.2 $\%$.

Mean hospital stay was 4 days. The operative mortality was $60.7 \%(n=17)$. Between 2006 and 2013 the mortality was $65 \%$ (23 operated, 15 deaths) and between 2013 to 2020 was $40 \%$ (5 operated 2 deaths). Three patients died postoperatively for non-operative causes (one for intestinal bleeding and two for sepsis). Four patients (14.3\%) needed postoperative HD and one $(3.6 \%)$ had cerebrovascular event (CVE). No patient was re-operated for bleeding.

When we compare those survivors and non-

Table 2. Univariate analysis for hospital mortality.

\begin{tabular}{|c|c|c|c|c|}
\hline Variables & Variables & $\begin{array}{l}\text { Survivors } \\
(n=11)\end{array}$ & $\begin{array}{l}\text { Nonsurvivors } \\
(n=17)\end{array}$ & P value \\
\hline Age & & $66.7 \pm 9.8$ & $73.8 \pm 6.8$ & 0,099 \\
\hline \multicolumn{2}{|l|}{ Gender } & $5(455 \%)$ & $9(529 \%)$ & 0699 \\
\hline & $M$ & $6(54.5 \%)$ & $8(47.1 \%)$ & \\
\hline $\mathrm{HT}$ & & $5(45.5 \%)$ & $4(23.5 \%)$ & 0.225 \\
\hline IDDM & & $5(45.5 \%)$ & $7(41.2 \%)$ & 0.823 \\
\hline PRE CRE & & $1.33 \pm 1.1 \mathrm{mg} / \mathrm{dL}$ & $2.25 \pm 1.4 \mathrm{mg} / \mathrm{dL}$ & 0.076 \\
\hline PRE DIA & & 0 & $5(29.4 \%)$ & 0.047 \\
\hline CVE & & 0 & 0 & \\
\hline Reop & & 0 & 0 & \\
\hline PCI DIA & & $8(72.7 \%)$ & $13(76.5 \%)$ & 0.823 \\
\hline PRE IABP & & $5(45.5 \%)$ & $12(70.6 \%)$ & 0.184 \\
\hline \multicolumn{5}{|l|}{ INF.LOC. } \\
\hline & NON ANT & $1(9.1 \%)$ & $4(23.5 \%)$ & 0.350 \\
\hline Card. SHO & & $3(27.3 \%)$ & $15(58.8 \%)$ & 0.102 \\
\hline UNS.ANG & & $3(27.3 \%)$ & $10(58.8 \%)$ & 0.102 \\
\hline$E F \%$ & & 35.9 & 34.7 & 1.0 \\
\hline Postop. IABP & & $6(54.5 \%)$ & $4(23.5 \%)$ & 0.094 \\
\hline CON.CABG & & $8(72.7 \%)$ & $7(41.2 \%)$ & 0.102 \\
\hline Leng. STA. & & $13(12-13.5)$ & $2(1-3.25)$ & $<0.001$ \\
\hline Post. CVE & & $1(9.1 \%)$ & 0 & 0.206 \\
\hline RRT & & $1(9.1 \%)$ & $3(17.6 \%)$ & 0.527 \\
\hline RE-Expo & & 0 & 0 & \\
\hline Inot. Agent & & $11(100 \%)$ & $17(100 \%)$ & \\
\hline
\end{tabular}

F: female, M: male, HT: hypertension, IDDM: insulin-dependent diabetes mellitus, PRE. CRE: preoperative creatinine, PRE. DIA: preoperative dialysis, PRE.IABP: preoperative intra-aortic balloon pump insertion, INF LOC: infarct localization, UNS. ANG: unstable angina, EF: ejection fraction, POSTOP. IABP: postoperative intra-aortic balloon pump insertion, CON.CABG: concomitant coronary artery bypass grafting, LENG.STA: length of stay in hospital, POST. SVE: postoperative cerebrovascular event, RRT: renal replacement therapy, RE-EXPO: re-exploration, INOT. AGENT: inotropic agent. 
Table 3. Multivariate regression analysis of independent predictors of hospital mortality

\begin{tabular}{|c|c|c|c|c|}
\hline \multirow[t]{2}{*}{ Variable } & \multirow[t]{2}{*}{ Exp (B) (Odds ratio) } & \multicolumn{2}{|c|}{ 95\% Confidence Interval for $\operatorname{Exp}(B)$} & \multirow[t]{2}{*}{ p value } \\
\hline & & Lower Bound & Upper Bound & \\
\hline Age & 1.226 & 0.999 & 1.506 & 0.051 \\
\hline Card.Shock & 13.469 & 1.072 & 169.180 & 0.044 \\
\hline INF.LOC. & 0.627 & 0.043 & 9.196 & 0.733 \\
\hline IDDM & 2.438 & 0.289 & 20.552 & 0.413 \\
\hline Gender $=F$ & 1.112 & 0.128 & 9.701 & 0.923 \\
\hline Con.Cabg & 0.263 & 0.051 & 1.355 & 0.110 \\
\hline
\end{tabular}

CARD: cardiogenic, INF.LOC: infarct localization, IDDM: insulin-dependent diabetes mellitus, F: female, CON.CABG: concomitant coronary artery bypass grafting.

survivors (Table 2) the only thing which statistically significant was length of stay in hospital. In survivors it was 13 days when it was 2 days in non-survivors group $(p<0.001)$. One patient in survivor group stayed in hospital for 107 days. The mortality rate was $76.9 \%$ in the presence of cardiac shock on admission, while in non-shock patients was $46.6 \%$, but it was statistically insignificant $(p=0.102)$. Preoperative creatinine value was $1.33 \mathrm{mg} / \mathrm{dL}$ in survivors and 2.25 $\mathrm{mg} / \mathrm{dL}$ in non-survivors $(\mathrm{p}=0.076)$. Infarct localization had no effect on survival between groups $(p=0.330)$. Concomitant CABG performed in 8 patients $(72.7 \%)$ in survivor and 7 patients $(41.2 \%)$ in non-survivor group. Preoperative IABP placement was $45.5 \%$ $(n=5)$ in survivors and $70.6 \%(n=12)$ in non-survivors $(p=0.184)$. Median age was $66.7 \pm 9.8$ in survivors when it was $73.8 \pm 6.8$ in non-survivors $(p=0.099)$.

We use inotropic agents for all our patients routinely, $5 \mu \mathrm{g} / \mathrm{kg} / \mathrm{m}$ dopamine and $0.05 \mu \mathrm{g} / \mathrm{kg} / \mathrm{m}$ noradrenaline according to date of surgery (we used noradrenaline after the year 2008).

\section{DISCUSSION}

Our 30-day mortality was high $(60.7 \%)$ compared to the literature (4-7). It might be related to some factors like cardiogenic shock on admission, time to surgery, infarct area and age. The patients whom had cardiogenic shock on admission had a higher mortality rate $(n=13$ cardiogenic shock and $n=10$ died,76.9\%). Non-cardiogenic shock patients had much lower mortality rates than shock patients $(n=15$ patients $n=7$ died $46.6 \%$ ). Cardiogenic shock on admission was independent predictor in our study like lots of the others (8-13) (Table 3). Also two of our patients died for non-cardiac related causes.

IABP support will improve coronary blood supply and that will increase the contraction of heart but there is no data to confirm this situation's positive effect on early mortality $(14,15)$. We inserted preoperatively 17 of 28 patients and 12 of them died. In the survivor group need of IABP is lower than non-survivors (45.5\%), we thought; in survivor group, cardiac output was better than non-survivors on admission, however postoperative need of IABP was higher in survivors group but it was statistically insignificant $(p=0.094)$. Some studies found that the insertion of IABP to the PMIVSD patients could be associated with the higher mortality $(16,17)$ but it might be related to that we usually insert the IABP to hemodynamically unstable and critical patients.

Early surgery is the recommended treatment for PMIVSD patients and its mortality lower than the medically treated patients. We operated all of the patients at least 48 hours after admission to the hospital. Maybe one of the reasons can be this for our high hospital mortality. Because of the fragile cardiac tissue over the VSD and unstable cardiac situation, the decision of immediate surgery is challenging. If the patients are hemodynamically stable delaying the operation should be considered. Because delaying the operation lets you a better fibrotic infarct tissue to put the VSD patch sutures. But Fukushima et al. found their 30 -day mortality as $35 \%$, although they did not postpone surgery for more than 48 hours.

Concomitant CABG performed to improve left ventricular contraction in 15 patients. Our study showed no beneficial effect on its protectiveness for left ventricle, despite some other studies reported beneficial effect $(18,19)$. We didn't use transcatheter closure (TCC) for our patients because there were no experienced interventional operation team for this treatment. Omar et al. found no difference in mortality between early surgery and early TCC ( $54 \pm 32 \%$ vs 56 $\pm 23 \%$ respectively, $P=0.82)(20)$. Same study and many of others (21-25) showed that early TCC had higher mortality rate than late repair. We could not use extracorporeal membrane oxygenator (ECMO) and left ventricular assist device (LVAD) for our PMIVSD 
patients until 2014 because of procedural problems. Many of the literature use them for patients who had cardiogenic shock in admission or postoperative cardiogenic shock caused by residual shunts or for any reasons (26). It might help to improve cardiac output.

Our study has limitations. First of all; this retrospective study is based on a cohort from a single tertiary center so our patient population was small and the statistical power is limited. Our surgical team has 6 surgeons during the study and they have different choices for surgical technique, plegia usage for myocardial protection and surgical materials. Right ventricular function was not measured throughout the study period and we did not include them. It was suggesting a risk factor for 30-day mortality in many papers (27-30).

\section{CONCLUSION}

In conclusion timing of the surgery for PMIVSD patients is still challenging. Further strategies like implanting LVAD or percutaneous devices and waiting for a while before the surgery will be the better approach for PMIVSD patients.

Conflict of interest: Authors declare that there is no conflict of interest between the authors of the article.

Financial conflict of interest: Authors declare that they did not receive any financial support in this study.

Address correspondence to: Serkan Yildirim, Necmettin Erbakan University, Meram Faculty of Medicine, Department of Cardiovascular Surgery, Konya, Turkey e-mail: serkaneo1@gmail.com

\section{REFERENCES}

1. Lundberg S, Soderstrom J. Perforation of the interventricular septum in myocardial infarction. A study based upon an autopsy material. Acta Med Scand 1962;172:413-8.

2. Madsen JC, Daggett WM Jr. Repair of postinfarction ventricular septal defects. Semin Thorac Cardiovasc Surg 1998;10(2):117-27.

3. O'Gara PT, Kushner FG, Ascheim DD, et al. 2013 ACCF/ AHA guideline for the management of ST-elevation myocardial infarction: A report of the American College of Cardiology Foundation/American Heart Association Task Force on Practice Guidelines [published correction appears in Circulation 2013;(24):128(25):e481]. Circulation 2013;127(4):e362-425.

4. Yip HK, Wu CJ, Chang HW, et al. Cardiac rupture complicating acute myocardial infarction in the direct percutaneous coronary intervention reperfusion era. Chest 2003;124:56571.

5. Nozoe M, Sakamoto T, Taguchi E, et al. Clinical manifestation of early phase left ventricular rupture complicating acute myocardial infarction in the primary $\mathrm{PCl}$ era. J Cardiol 2014; 63:14-8.

6. Poulsen SH, Praestholm M, Munk K, et al. Ventricular septal rupture complicating acute myocardial infarction: Clinical characteristics and contemporary outcome. Ann Thorac Surg 2008;85:1591-6.

7. Malhotra A, Patel K, Sharma P, et al. Techniques, timing and prognosis of post infarct ventricular septal repair: A re-look at old dogmas. Braz J Cardiovasc Surg 2017;32:147-55.

8. Cooley DA. Postinfarction ventricular septal rupture. Semin Thorac Cardiovasc Surg 1998;10:100-4.

9. David TE, Armstrong S. Surgical repair of postinfarction ventricular septal defect by infarct exclusion. Semin Thorac Cardiovasc Surg 1998;10:105-10.

10. Deville C, Fontan F, Chevalier JM, et al. Surgery for postinfarction ventricular septal defect: Risk factors for hospital death and long-term results. Eur J Cardio-thorac Surg 1991;5:167-75

11. Skillington PD, Davies RH, Luff AJ, et al. Surgical treatment of infarct-related ventricular septal defects. Improved early results combined with analysis of late functional status. J Thorac Cardiovasc Surg 1990;99:798-808.

12. Dalrymple-Hay MJR, Monro JL, Livesey SA, et al. Postinfarc tion ventricular septal rupture; the Wessex experience. Semin Thorac Cardiovasc Surg 1998;10:111-6.

13. Hill JD, Stiles QR. Acute ischemic ventricular septal defect. Circulation 1989;79(Suppl 1):112-5.

14. Deville C, Fontan F, Chevalier JM, et al. Surgery for postinfarction ventricular septal defect: Risk factors for hospital death and long-term results. Eur J Cardio-thorac Surg 1991;5:167-75

15. Anderson DR, Adams S, Bhat A, et al. Post-infarction ventricular septal defect: The importance of site of infarction and cardiogenic shock on outcome. Eur J Cardio-thorac Surg 1989;3:554-7

16. Moore CA, Nygaard TW, Kaiser DL, et al. Postinfarction ventricular septal rupture: the importance of location of infarction and right ventricular function in determining survival. Circulation 1986;74:45 \pm 55 .

17. Angelini GD, Penny WJ, Ruttley MS, et al. Post-infarction ventricular septal defect: The importance of right ventricular coronary perfusion in determining surgical outcome. Eur $\mathrm{J}$ Cardio-thorac Surg 1989;3:156 \pm 161

18. Muehrcke DD, Daggett WM Jr, Buckley MJ, et al. Postinfarct ventricular septal defect repair: Effect of coronary artery bypass grafting. Ann Thorac Surg 1992;54:876-82; discussion 882-3.

19. Barker TA, Ramnarine IR, Woo EB, et al. Repair of postinfarct ventricular septal defect with or without coronary artery bypass grafting in the northwest of England: A 5-year multi-institutional experience. Eur J Cardiothorac Surg 2003; 24:940-6.

20. Omar S, Morgan GL, Panchal HB, et al. Management of post-myocardial infarction ventricular septal defects: A critical assessment. J Interv Cardiol. 2018;31(6):939-48.

21. Dalrymple-Hay MJ, Monro JL, Livesey SA, et al. Postinfarction ventricular septal rupture: The Wessex experience. Semin Thorac Cardiovasc Surg 1998;10:111-6.

22. Di Summa M, Actis Dato GM, Centofanti $P$, et al. Ventricular septal rupture after a myocardial infarction: Clinical features and long term survival. J Cardiovasc Surg (Torino) 
1997;38:589-93.

23. Cerin G, Di Donato M, Dimulescu D, et al. Surgical treatment of ventricular septal defect complicating acute myocardial infarction. Experience of a north Italian referral hospital. Cardiovasc Surg Lond Engl 2003;11:149-54.

24. Noguchi K, Yamaguchi A, Naito K, et al. Short-term and longterm outcomes of postinfarction ventricular septal perforation. Gen Thorac Cardiovasc Surg 2012;60:261-7.

25. Thiele H, Lauer B, Hambrecht $R$, et al. Short- and longterm hemodynamic effects of intra-aortic balloon support in ventricular septal defect complicating acute myocardial infarction. Am J Cardiol 2003;92:450-4.

26. Egbe AC, Poterucha JT, Rihal CS, et al. Transcatheter closure of postmyocardial infarction, iatrogenic, and postoperative ventricular septal defects: The Mayo Clinic experience. Cathet and Card Inter 2015 86:1264-70.
27. Blanche $C$, Khan SS, Chaux A, et al. Postinfarction ventricular septal defect in the elderly: Analysis and results. Ann Thorac Surg 1994;57:1244-7.

28. Jones MT, Schofield PM, Dark JF, et al. Surgical repair of acquired ventricular septal defect: Determinants of early and late outcome. J Thorac Cardiovasc Surg 1987;93:680-6.

29. Labrousse L, Choukroun E, Chevalier JM, et al. Surgery for post infarction ventricular septal defect (VSD): Risk factors for hospital death and long term results. Eur J Cardiothorac Surg 2002;21:725-31.

30. David TE, Dale L, Sun Z. Postinfarction ventricular septal rupture: Repair by endocardial patch with infarct exclusion. J Thorac Cardiovasc Surg 1995;110:1315-22. 